\title{
Odonate fauna (Insecta: Odonata) from a locality in San Marcos River in the Sierra Norte of Puebla, Mexico
}

\author{
J.D. Silva-Hurtado ${ }^{\mathrm{a}}$, J. Márquez ${ }^{\mathrm{a} *}$, J.A. Escoto-Moreno $^{\mathrm{b}}$ and A.P. Martínez-Falcón ${ }^{\mathrm{c}}$ \\ ${ }^{a}$ Laboratorio de Sistemática Animal, Centro de Investigaciones Biológicas, Universidad Autónoma del \\ Estado de Hidalgo, Mineral de la Reforma, Hidalgo, Mexico; ${ }^{b}$ Colección Zoológica, Departamento de \\ Biología, Centro de Ciencias Básicas, Universidad Autónoma de Aguascalientes, Aguascalientes, Mexico; \\ ${ }^{c}$ Laboratorio de Ecología de Comunidades, Centro de Investigaciones Biológicas, Universidad Autónoma \\ del Estado de Hidalgo, Mineral de la Reforma, Hidalgo, Mexico
}

(Received 18 February 2020; final version received 23 June 2020)

\begin{abstract}
Odonates have been recognized as an important group for evaluating ecosystems since they are used as bioindicators of the conservation status of the habitat they occupy, in addition to being generalist predators feeding on invertebrates and small vertebrates. In this work, the biodiversity of adult odonates from a locality near the San Marcos River, in Puebla, Mexico, is analyzed through systematic sampling performed during 2018. Species richness and composition patterns were analyzed and compared between the rainy and dry seasons; the results were also compared with those of similar studies at the regional level. There were six families, 21 genera and 37 species that represent about $40 \%$ of the 95 species registered in Puebla. Coenagrionidae, with Argia, was the best representative of the Zygoptera, and Libellulidae was the best for the Anisoptera. Three of the species collected in the San Marcos River increased the species number from 95 to 98 for Puebla, making it currently placed 14th of 32 Mexican states in terms of the species richness of odonates nationwide. According to the Chao 2 and Bootstrap estimators, the completeness of the inventory varied from $61 \%$ to $67 \%$ in the dry season, from $73 \%$ to $83 \%$ in the rainy season, and from $74 \%$ to $86 \%$ for the annual completeness. There were no significant differences in species richness and composition between the rainy and dry seasons. The species richness of odonates in this locality is the second highest known for Puebla and can still provide important data for this group.
\end{abstract}

Keywords: diversity; inventory completeness; composition; dragonfly; richness

\section{Introduction}

The current knowledge of the aquatic ecosystems of Mexico is based on a limnological tradition that emerged during the 1950s, which mainly describes the lentic environments (AlonsoEguíaLis, Mora, Campbell, \& Springer, 2014). Studies on lotic systems and their fauna began in the 1970s, with groups such as Odonata, Trichoptera, Megaloptera and Diptera, with the latter given special attention for its medical importance (Alonso-EguíaLis et al., 2014).

*Corresponding author. Email: marquezorum@gmail.com 
Odonates are generalist predators since they feed on invertebrates and small vertebrates (Gómez-Anaya, 2008). Because they need water to reproduce and survive, they are found in almost all the freshwater bodies of the world (González-Soriano \& Novelo-Gutiérrez, 2014). The species of odonates are important in the evaluation of ecological integrity of ecosystems because they are used as indicators of water quality and monitor the effects of environmental change on the ecosystems that are in process of recovery (Gómez-Anaya, 2008).

In the last update (18 December 2019) of the electronic publication "Mexican Odonata list", 362 species of odonates were registered in the country, of which 95 occur at the state of Puebla (González-Soriano \& Paulson, 2019). The records on that website, however, are provided only at the state level, and there are no publications or references to specimens deposited in institutional collections that support them. Therefore, this information should be viewed with reservation.

The state of Puebla is composed of five biogeographic provinces (Gulf of Mexico, Sierra Madre Oriental, Mexican Plateau, Transversal Volcanic Belt, Balsas Basin and Sierra Madre del Sur) and has different types of ecoregions (Morón, 2013). In the south of the state there are arid and semi-arid zones, while in the north-central portion of the state there are predominantly humid and sub-humid temperate ecoregions, and humid and sub-humid tropics. In the Sierra Norte of Puebla, there are different types of vegetation such as cloud forest, evergreen forest, deciduous forest and subdeciduous forest, which promote the development of a great diversity of organisms (Toledo \& Ordóñez, 1993).

Most of the odonate records in the state of Puebla come from the following studies: GómezAnaya \& Novelo-Gutiérrez (1993) analyzed the fauna of odonates in the Sierra de Huauchinango located north of the state, where they found 59 species of 28 genera and eight families. This study included a locality on San Marcos River but was located in Villa Ávila Camacho in the municipality of Xicotepec de Juárez. Tapia-Rojas, Novelo-Gutiérrez, \& López-Olguín (2005) found 31 species of 23 genera and nine families from samples in Atlixco, Cuautlancingo, Flor del Bosque and Santo Domingo Huehuetlán el Grande. Cuevas-Yáñez (2007) recorded 51 species, 31 genera and 10 families in two locations in the municipality of Zihuateutla: Patla Hydroelectric Power Plant (El Pozo) and the Tecpatlán River. Escoto-Moreno, Márquez, and Asiain (2020) contributed with four new records for Puebla, with three from the San Marcos River, in the municipality of Tlacuilotepec, thus increasing numbers from 95 to 98 species; therefore, the state occupies the 14th place in the ranking of the species richness of odonates in Mexico (GonzálezSoriano \& Paulson, 2019).

The municipality of Tlacuilotepec of the Sierra Norte of Puebla is of great cultural importance since most of its population is indigenous. In addition, it is biologically relevant because it has varied vegetation, including parts with cloud forest, tropical deciduous forest and sub-tropical deciduous forest, with virtually no formal studies about almost any biological group (TapiaRojas et al., 2005). The municipality, including the study location known as the San Marcos River, belongs to the biogeographical province of the Sierra Madre Oriental (Amparo-Bélgica, Contreras-Jiménez, \& De Gante-Cabrera, 2012) and to the Tuxpan River Basin. In this basin, actions are being taken to reduce the anthropogenic impact on the environment, particularly the energy impact, as part of the conservation strategies of the regional ecological system of the Tuxpan River Basin. Finally, it is close to the protected natural area of the Necaxa River Basin (Tapia-Rojas et al., 2005).

The objective of this study is to determine the biodiversity of adults of the order Odonata in a locality of the San Marcos River, the municipality of Tlacuilotepec, in the Sierra Norte of Puebla. In particular, it is desired to estimate the completeness of the inventory to compare the richness and composition of the odonate fauna between the dry and rainy seasons. 


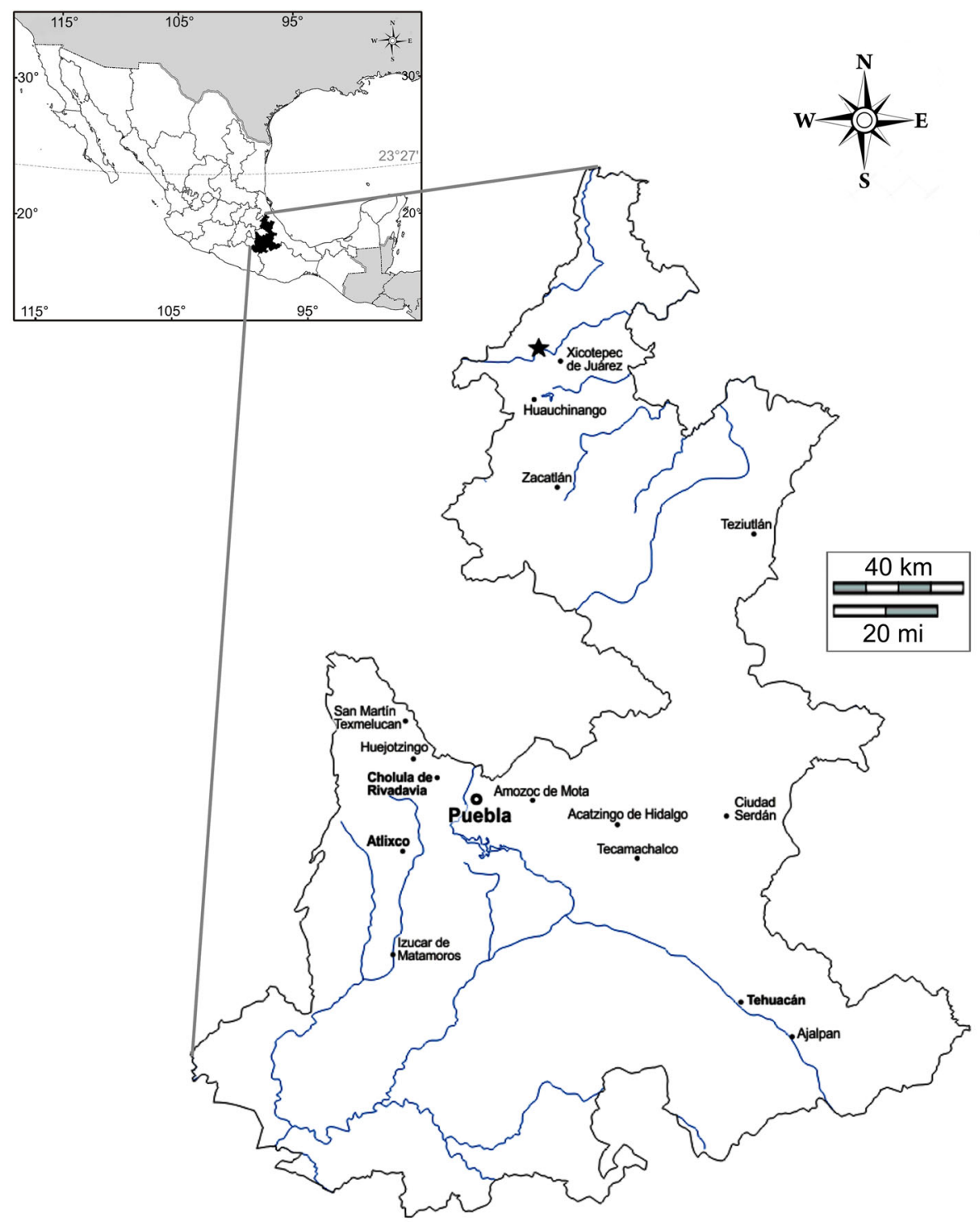

Figure 1. Geographic location of the sampling site (marked with a black star near Xicotepec de Juárez) in Tlacuilotepec, Puebla (modified from INEGI, 2018, 2019).

\section{Materials and methods}

The study was carried out in a locality of the San Marcos River, municipality of Tlacuilotepec, in the Sierra Norte of Puebla. The geographical coordinates are $20.322897^{\circ} \mathrm{N}$ and $98.043141^{\circ}$ $\mathrm{W}$ (Figure 1). The vegetation observed in the place is tropical semi-deciduous forest (Figure 2). Some dominant elements are Brosimum sp., Vitex sp., Bursera sp., Nectandra sp., and Sterculia sp., in addition to some areas transformed into grassland for cattle (Figure 2). 


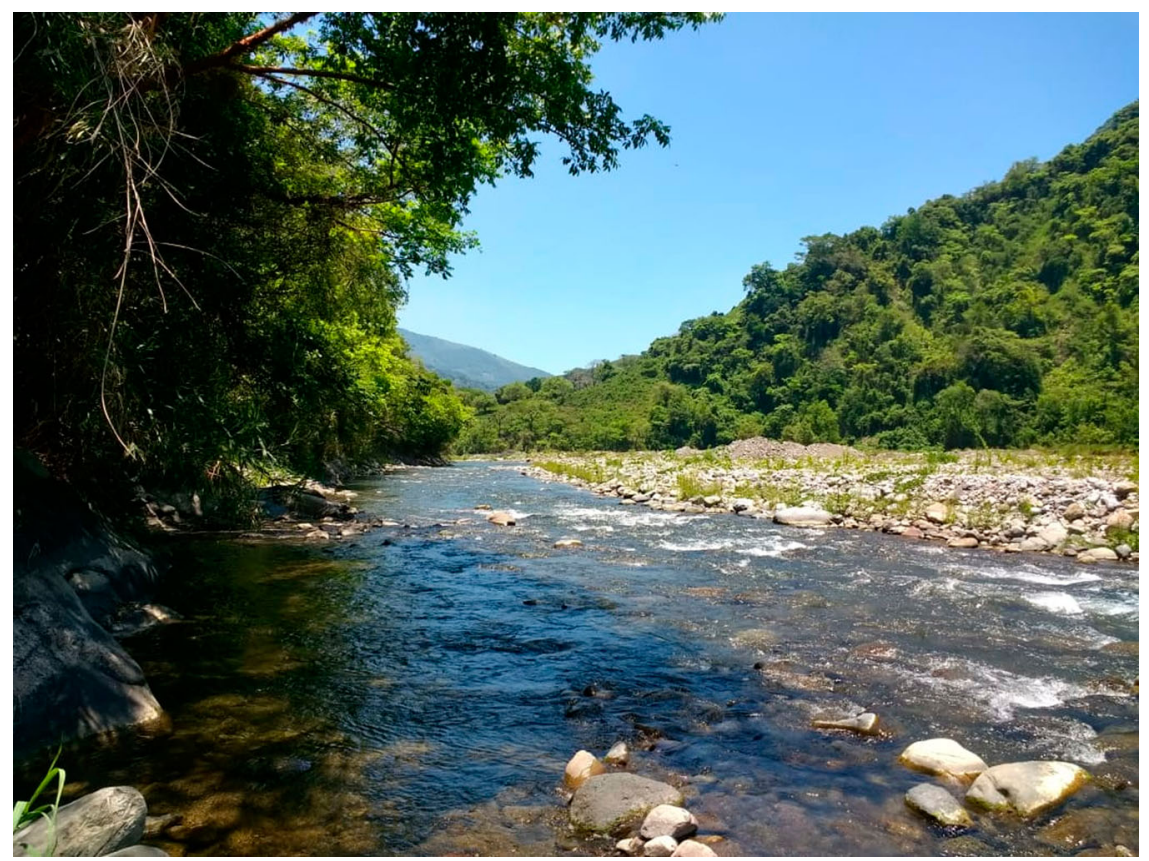

Figure 2. Photo of the locality San Marcos River showing the vegetation type around the river (@photo J.D. Silva-Hurtado).

The collections were made from April to November of 2018, with monthly and biweekly visits; the latter were complementary, taken only in September and October, and considered as sub-replicas in the analyses. This strategy aimed to improve the completeness of the inventory since greater adult emergence has been observed during the months of the highest rainfall (Wolf, Matthias, \& Roldan, 1988). Each sampling event was for a period of $5 \mathrm{~h}$ performed by one person, with a total of $45 \mathrm{~h}$ of sampling effort. The transects were made within approximately $500 \mathrm{~m}$ on both sides of the river in order to look for odonates in places near the bodies of water (rivers, streams and surrounding vegetation). Each collection event was done during sunny days to favor the capture of adult Odonata specimens, since they are more active during these periods. The collected specimens were immersed in $100 \%$ commercial acetone to sacrifice and preserve them (Escoto-Moreno, 2015).

The specimens were identified based on specialized literature (Escoto-Moreno, 2015; Garrison, 1994; Garrison, von Ellenrieder, \& Louton, 2006, 2010; Heckman, 2006; PalacinoRodríguez, 2011) and by a comparison with previously identified and deposited material from the Entomological Collection of the Biological Research Center (CE-UAEH) and Zoological Collection of the Autonomous University of Aguascalientes (CZ-UAA). The individuals sampled as part of this study were deposited in these collections. The classification criteria followed are those proposed by Dijkstra et al. (2013).

The completeness of the inventory was estimated for the dry season (April, May, June, and November), for the rainy season (July, August, September, and October), and for all samples in total using the Chao 2 and Bootstrap estimators, which are based on presence-absence data (Villareal et al., 2006); the use of two or more estimators provide information that helps us to understand the variation that can exist when the completeness of the inventory are estimated (Cuevas-Yañez, Espinosa-Rivera, Martínez-Falcón \& Córdoba-Aguilar, 2017; Novelo-Gutiérrez 
\& Gómez-Anaya, 2009). The formulas for these estimators are (Moreno, 2001):

$$
\text { Chao }_{2}=S+\frac{L^{2}}{2 M} ; \text { Bootstrap }=S+\Sigma(1-p j)^{n}
$$

The location of each sampling month in one of the two seasons was chosen based on what was indicated by García (1974) and corroborated by Santillán Gutiérrez, Dávila-Vázquez, Sánchez, Torres, \& de Jesús (2013). The latter authors mentioned that the climatic variables of a region are defined by seasonality. In temperate regions with very defined variables, seasonality can be recognized very easily, unlike subtropical or tropical zones, such as the San Marcos River, which is part of the Cazones River Basin, where seasonality is very difficult to define. The duration of the dry or rainy seasons varies yearly; in this zone there is precipitation during almost all the year, but it is possible to define a period from July to October where precipitation oscillates between 100 and $200 \mathrm{~mm}$, and this period can be considered as the rainy season. Meanwhile in the dry season (November to June) a considerable decrease in precipitation can be observed, i.e. 0-90 mm.

Given the low inventory reliability, species richness comparisons between seasons were performed using the extrapolation method. This method creates randomizations of estimated species $\left(S_{\text {est }}\right)$ per sampling event. Here the method was applied using the EstimateS 9 program (Colwell, 2013), which doubled the number of samples to estimate beyond the observation values and resulted in the number of species expected if more samples had been performed.

The composition of the different sampling months was compared with their respective seasons, with the help of the Jaccard index and a PERMANOVA analysis using the PRIMER v7 program (Clarke \& Gorley, 2015). Finally, a multidimensional metric scaling (MDS) was performed to show the differences between seasons.

\section{Results}

In total, 246 adult specimens of odonates belonging to six families, 21 genera and 37 species were collected (Table 1). Anisoptera is represented by 20 species and Zygoptera by 17. The largest number of Zygoptera species was found in the Coenagrionidae family (13 species), with Argia represented by nine species. On the other hand, for Anisoptera the Libellulidae family had higher species richness (16 species), with several genera, such as Brechmorhoga, Dythemis, Erythrodiplax, Libellula and Orthemis, each with two species (Table 1).

Regarding the completeness of the inventory, the achieved completeness was between $61 \%$ (31 expected species, Chao2) and 67\% (28 expected species, Bootstrap) for the dry season; while for the rainy season it was $73 \%$ (49 expected species, Chao2) and 83\% (43 expected species, Bootstrap). The total completeness (over 8 months) was between $74 \%$ (50 expected species, Chao2) and 86\% (43 expected species, Bootstrap); that means 13 species (Chao2) and six species (Bootstrap) are missing to add to the total inventory. The analysis of estimated species richness $\left(S_{\text {est }}\right)$ by comparing the confidence intervals resulted in no significant differences between the two seasons (dry and rainy), because the confidence intervals overlap for both the observed and extrapolated data (Figure 3a).

The similarity between seasons was 0.48 according to the Jaccard index, which was used to perform a PERMANOVA analysis, but no significant differences were observed between the two seasons $\left(F_{\text {pseudo }}=1.90, d f=1, p=0.11\right)$. As for the exclusivity of species for the time of the year, an exclusive species was found for the dry season and 18 for the rainy season, while another 18 are shared between both seasons, supporting the result obtained by the Jaccard index (Figure 3b). 
Table 1. Taxonomic list of Odonata of the San Marcos River, Tlacuilotepec, Puebla, with their respective months of sampling.

\begin{tabular}{|c|c|}
\hline Suborder Zygoptera, Superfamily Calopterygoidea, Family Calopterygidae & Months of sampling \\
\hline Hetaerina americana (Fabricius, 1798) & Sep, Oct \\
\hline Hetaerina cruentata (Rambur, 1842) & Apr, May, Jun, Jul, Sep, Oct, Nov \\
\hline Hetaerina occisa (Hagen in Selys, 1853) & Sep \\
\hline \multicolumn{2}{|l|}{ Superfamily Coenagrionoidea, Family Coenagrionidae } \\
\hline Acanthagrion quadratum Selys, 1876 & Sep, Oct, Nov \\
\hline Apanisagrion lais (Brauer in Selys, 1876) & Aug \\
\hline Argia anceps Garrison, 1996 & Aug, Sep, Oct \\
\hline Argia extranea (Hagen, 1861) & Sep, Nov \\
\hline Argia frequentula Calvert, 1907 & Oct \\
\hline Argia immunda (Hagen, 1861) & Sep, Oct \\
\hline Argia sp. group oculata & Sep, Oct, Nov \\
\hline Argia oenea Hagen in Selys, 1865 & Apr, May, Jun, Jul, Sep, Oct, Nov \\
\hline Argia rhoadsi Calvert, 1902 & Aug \\
\hline Argia translata Hagen in Selys, 1865 & Sep \\
\hline Argia ulmeca Calvert, 1902 & Sep \\
\hline Protoneura cara Calvert, 1903 & Sep \\
\hline Telebasis salva (Hagen, 1861) & Sep, Oct, Nov \\
\hline \multicolumn{2}{|l|}{ Superfamily Platystictoidea, Family Platystictidae } \\
\hline Palemnema paulicoba Calvert, 1931 & Sep \\
\hline \multicolumn{2}{|l|}{ Suborder Anisoptera, Superfamily Aeshnoidea, Family Aeshnidae } \\
\hline Remartinia luteipennis (Burmeister, 1839) & Sep, Oct, Nov \\
\hline Rhionaeschna psilus (Calvert, 1947) & Oct \\
\hline \multicolumn{2}{|l|}{ Superfamily Gomphoidea, Family Gomphidae } \\
\hline Erpetogomphus bothrops Garrison, 1994 & Sep, Nov \\
\hline Phyllogomphoides suasus (Selys, 1859) & Aug, Sep, Oct, Nov \\
\hline \multicolumn{2}{|l|}{ Superfamily Libelluloidea, Family Libellulidae } \\
\hline Brechmorhoga tepeaca Calvert, 1908 & Sep \\
\hline Brechmorhoga vivax Calvert, 1906 & Apr, May, Jun, Jul, Aug, Sep, Oct, Nov \\
\hline Dythemis nigra Martin, 1897 & Sep \\
\hline Dythemis nigrescens Calvert, 1899 & May, Sep, Oct \\
\hline Dythemis sterilis Hagen, 1861 & Nov \\
\hline Erythemis collocata Hagen, 1861 & Sep \\
\hline Erythrodiplax fusca (Rambur, 1842) & Apr, May, Jun, Oct, Nov \\
\hline Erythrodiplax umbrata (Linnaeus, 1758) & Aug \\
\hline Libellula croceipennis Selys, 1868 & Jul, Aug, Sep, Oct \\
\hline Libellula herculea Karsch, 1889 & Sep \\
\hline Macrothemis pseudimitans Calvert, 1898 & Apr, May, Jul, Sep, Nov \\
\hline Orthemis discolor (Burmeister, 1839) & Jun, Jul, Sep, Oct, Nov \\
\hline Orthemis ferruginea (Fabricius, 1775) & Jul, Oct \\
\hline Pantala flavescens (Fabricius, 1798) & Oct, Nov \\
\hline Perithemis intensa Kirby, 1889 & Sep, Oct, Nov \\
\hline Pseudoleon superbus (Hagen, 1861) & May, Sep, Oct, Nov \\
\hline
\end{tabular}

\section{Discussion}

Coenagrionidae of the suborder Zygoptera and Libellulidae of the suborder Anisoptera were the families with the greatest species richness in the study area. These families are also the most diverse in the world in their corresponding suborders, which is the main reason why more of these species were found in the study area (Schorr \& Paulson, 2019).

A greater dominance of the Anisoptera suborder was observed in the field, especially of some species of the Libellulidae family, such as Libellula croceipennis Selys, 1868 and Orthemis discolor (Burmeister, 1839), which were noticeably territorial because of the search for a reproductive partner: up to five males were observed fighting for a territory, making other species flee from the site (Silva-Hurtado, 2019; Valenzuela-Rojas, 2015). On the other hand, Brechmorhoga vivax Calvert, 1906 and Argia oenea Hagen in Selys, 1865 were found in river pools 

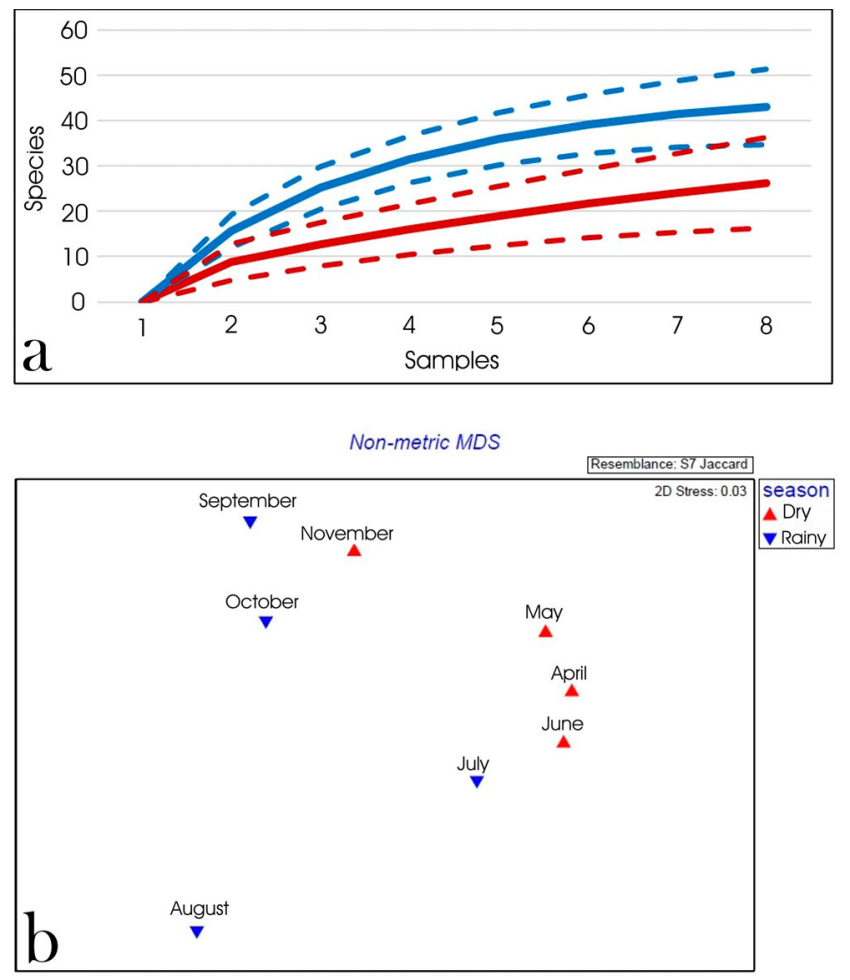

Figure 3. (a) Curves of species richness estimated per season; the red color represents the dry season and blue the rainy season, with their respective confidence intervals marked with the dotted lines. (b) Multidimensional scaling (MDS) using the Jaccard index considering the sampling events and the seasons of the year (dry and rainy) as the grouping factor.

with continuous water flow, where copulation or oviposition was frequently observed in several of the sampling months (Córdoba-Aguilar, 1994; Silva-Hurtado, 2019). Due in part to the above, the species that occurred more through the sampling events were Brechmorhoga vivax, Argia oenea, Hetaerina cruentata (Rambur, 1842), Erythrodiplax fusca (Rambur, 1842) and Libellula croceipennis.

Regarding previous studies conducted in the Sierra Norte of Puebla, one of the sampling sites of the work of Gómez-Anaya \& Novelo-Gutiérrez (1993) was in the San Marcos River but in the municipality of Xicotepec de Juárez, particularly in the town of Ávila Camacho, where they found 27 species, 14 of which are shared with this work. Despite proximity, each locality has unshared species, which may be because of the variety of conditions found in these two sites. For example, compared with Tlacuilotepec (on the San Marcos River), in Ávila Camacho the temperature is warmer, it has a high evergreen forest and it is located at a lower altitude $(240 \mathrm{~m})$.

The study done by Cuevas-Yáñez (2007) was performed in two locations in the municipality of Zihuateutla, which is close to Tlacuilotepec. In the town of El Pozo, a greater species richness was obtained (46) compared with the San Marcos River, of which 25 species are shared. As for the second locality of the study referred to, the Tecpatlán River, 31 species were found, sharing 19 with the San Marcos River. The Coenagrionidae and Libellulidae families were the best represented in all three locations.

On the other hand, one of the study sites in the work conducted by Escoto-Moreno (2015) is in Tenango de Doria, Hidalgo. Although it does not correspond to the Sierra Norte of Puebla, it is very close: in fact, it is the closest place to the headwaters of the San Marcos River. On this 
site, five families, eight genera and 10 species were registered, four of which are shared with this study.

The three aforementioned studies were carried out in more than one locality, and individually they do not exceed 35 species, except for the locality of El Pozo in the Cuevas-Yáñez (2007) study, where 46 species were recorded. The sampling effort, however, was greater in time and the number of people, and larvae were also included. If the two locations of the San Marcos River of the Gómez-Anaya \& Novelo-Gutiérrez study (1993) and the present study were combined, 50 species would be registered, representing a high species richness for this order, although still smaller than the biodiversity recorded for the dragonfly "hot spots" in the country, which are Los Tuxtlas, Veracruz, the Huasteca Potosina and some regions of the state of Chiapas (EscotoMoreno, Márquez, \& Novelo-Gutiérrez, 2014).

The lack of completeness may be due to factors such as limited experience in the capture of specimens, migratory species, or species that because of their phenology were not found in an adult state, but which could probably be present in juvenile form in the water (EscotoMoreno, 2015; Valenzuela-Rojas, 2015). On the other hand, the sampling effort was increased to biweekly sampling in two months of the rainy season. Performing these sub-replicas could be recommended since the probability of capturing more species and having a better completeness is considerably increased, as observed in the results of the rainy season, which were higher and close to $100 \%$ compared with the dry season. However, it is necessary to make the same sampling effort during all the collection months, including the use of sub-replicas, and based on the results, to justify or not the recommendation previously made. According to Jiménez \& Hortal (2003), according to estimators, species richness is expected to reach an asymptote with values above to $70 \%$ of accuracy. However, to reach more of $95 \%$ of the inventory completeness would be a difficult task because the species richness and composition of a specific region varies over time caused by changes in species distribution, natural conditions that affect the functioning of organisms, and the existence of rare or wandering individuals (vagrants) (Adler \& Lauenroth, 2003).

One of the few studies that address estimates, richness and completeness of inventories is that of Novelo-Gutiérrez \& Gómez-Anaya (2009), which studied adult and juvenile odonates on an altitudinal gradient in the Sierra de Coalcomán, Michoacán state, Mexico. This site is located geographically on the opposite side to the Sierra Madre Oriental (where the site of the present study is located), on the western slope of the country. The authors collected 116 species, 44 genera and nine families. Using the Chao2, Bootstrap and Jackknife 2 estimators, they obtained very high percentages of completeness $(96.7 \%, 94.3 \%$ and $91.3 \%$, respectively, for each estimator), where the asymptote could be clearly seen in the graphs. This work shows that the collection of larvae is very important to obtain better results in completing the inventories.

As it was observed in the previously mentioned paper (Novelo-Gutiérrez \& Gómez-Anaya, 2009), the probability of studying odonates in early stages of their development, such as larvae, should also be considered since they can improve the study and the completeness of inventories. In addition to having an abundance of double or triple the amount of adults, the capture is random, so it is possible to work with relative abundances, unlike adults (Gómez-Anaya, 2008). For example, Escoto-Moreno (2015) recorded larvae that represented between $7 \%$ and $12 \%$ of the completeness of the inventory that was not obtained with adults.

The absence of significant differences in species richness between the two seasons compared may be due to biological aspects of the species but also to aspects of the sampling effort, such as the difficulty in capturing some individuals or the reduced initial experience in sampling. Other external aspects that could affect the development and appearance of organisms have already been mentioned before, such as exposure to sunlight and low rainfall, among others.

During the months with lower species richness (dry season), a greater dominance of individuals of few species was observed, while for the rainy months there was a considerable increase 
in richness and a decrease in the number of individuals. During the dry season, individuals (particularly males) tend to be more abundant because they have to prepare an optimal place for reproduction, and therefore the goal is to defend territories. While in the rainy season, the main goal is reproduction, and there is a greater probability of observing species in their adult phase, which are not regularly found the rest of the year because they are larvae inside the water bodies. All of the above are factors that can influence the results regarding the seasonal occurrence (Silva-Hurtado, 2019; Valenzuela-Rojas, 2015).

It can be concluded that the San Marcos River showed a high number of species of odonates. It is not possible to strictly compare our results with those of the studies carried out in Puebla State because the systematized studies, or those with estimates of species richness, are minimal for the odonates of Mexico. With the help of estimates and richness analysis, an approximation of the species richness of odonates in the studied locality was obtained. It is still necessary, however, to continue this study to improve the knowledge and understanding of the importance of the place in terms of the survival of odonates and other organisms that depend on the river.

\section{Acknowledgments}

We thank Julieta Asiain (Laboratorio de Sistemática Animal, UAEH) for her revision of the text and the edition of Figure 1. We thank Mary-Ann Hall for her English revision of the text. We thank Rodolfo Novelo-Gutiérrez, José Antonio Gómez-Anaya (Instituto de Ecología, A.C.), and an anonymous reviewer for the very helpful suggestions on this paper.

\section{References}

Adler, P. B., \& Lauenroth, W. K. (2003). The power of time: Spatiotemporal scaling of species diversity. Ecology Letters, 6(8), 749-756.

Alonso-EguíaLis, P., Mora, J. M., Campbell, B., \& Springer, M. (Eds.). (2014). Diversidad, conservación y uso de los macroinvertebrados dulceacuícolas de México, Centroamérica, Colombia, Cuba y Puerto Rico [Diversity, conservation and use of freshwater macroinvertebrates from Mexico, Central America, Colombia, Cuba and Puerto Rico]. Querétaro, México: Instituto Mexicano de Tecnología del Agua, Universidad Autónoma de Querétaro.

Amparo-Bélgica, C. C., Contreras-Jiménez, J. L., \& De Gante-Cabrera, V. H. (2012). Inventario pteridoflorístico del área de protección de recursos naturales "Cuenca hidrográfica del río Necaxa", porción Puebla, México. Polibotánica, $33,41-55$.

Clarke, K. R., \& Gorley, R. N. (2015). PRIMER v7: User Manual/Tutorial. Plymouth, UK: PRIMER-E.

Colwell, R. K. (2013). Estimates: Statistical estimation of species richness and shared species from samples. Version 9. Retrieved from http://purl.oclc.org/estimates.

Córdoba-Aguilar, A. (1994). Some observations of reproductive behavior in Brechmorhoga vivax Calvert (Odonata: Libellulidae). Notulae Odonatologicae, 4, 51-53.

Cuevas-Yáñez, K. (2007). Los odonatos (Insecta: Odonata) de la Hidroeléctrica de Patla (El Pozo) y el Rio Tecpatlán, Zihuateutla, Puebla, México. Dugesiana, 14(2), 83-91.

Cuevas-Yañez, K., Espinosa-Rivera, J. C., Martínez-Falcón, A. P., \& Córdoba-Aguilar, A. (2017). Are all Mexican odonate species documented? An assessment of species richness. Systematics and Biodiversity, 15(3), 253-258.

Dijkstra, K. D. B., Bechly, G., Bybee, S. M., Dow, R. A., Dumont, H. J., Fleck, G. . . Ware, J. (2013). The classification and diversity of dragonflies and damselflies (Odonata). Zootaxa, 3703(1), 36-45.

Escoto-Moreno, J. A. (2015). Taxonomía, diversidad y biogeografía de Odonata (Insecta) en la Sierra Madre Oriental de Hidalgo y Huayacocotla, Veracruz, México (Unpublished doctoral dissertation). Universidad Autónoma del Estado de Hidalgo, Mineral de la Reforma, Hidalgo, México.

Escoto-Moreno, J. A., Márquez, J., \& Asiain, J. (2020). New records of Odonata from central eastern Mexico. Proceedings of the Entomological Society of Washington, 122(1): 235-242.

Escoto-Moreno, J. A., Márquez, J., \& Novelo-Gutiérrez, R. (2014). Los odonatos (Insecta: Odonata) del estado de Hidalgo, México: situación actual y perspectivas. Revista Mexicana de Biodiversidad, 85, 1043-1053.

García, E. (1974). Distribución de la precipitación en la República Mexicana. Investigaciones Geográficas, 1(5), 7-20.

Garrison, R. W. (1994). A revision of the New World genus Erpetogomphus Hagen in Selys (Odonata: Gomphidae). Tijdschriftvoor Entomologie, 137, 173-269.

Garrison, R. W., von Ellenrieder, N., \& Louton, J. A. (2006). Dragonfly genera of the New World: An illustrated and annotated key to the Anisoptera. Baltimore, Maryland: John Hopkins University Press.

Garrison, R. W., von Ellenrieder, N., \& Louton, J. A. (2010). Damselfly genera of the New World: An illustrated and annotated key to the Zygoptera. Baltimore, Maryland: John Hopkins University Press. 
Gómez-Anaya, J. A. (2008). Ecología de los ensamblajes de larvas de odonatos (Insecta) y su uso potencial como indicadores de calidad ecológica en la Sierra de Coalcomán, Michoacán, México (Unpublished doctoral dissertation). Universidad Autónoma del Estado de Hidalgo, Mineral de la Reforma, Hidalgo, México.

Gómez-Anaya, J. A., \& Novelo-Gutiérrez, R. (1993). Odonata de la Sierra de Huauchinango, Puebla, México. Bulletin of American Odonatology, 1(4),71-73.

González-Soriano, E., \& Novelo-Gutiérrez, R. (2014). Biodiversidad de Odonata. Revista Mexicana de Biodiversidad, Suplemento, 85, 243-251.

González-Soriano, E., \& Paulson, D. (2019, December 18). Mexican Odonata list. Retrieved from https://www.puget sound.edu/academics/academic-resources/slater-museum/biodiversity-resources/dragonflies/mexican-odonata/.

Heckman, C. W. (2006). Encyclopedia of South American aquatic insects: Odonata-Anisoptera: Illustrated keys to known families, genera, and species in South America. Dordrecht: Springer.

Instituto Nacional de Estadística, Geografía e Informática (INEGI). (2018). Marco Geoestadístico Nacional. Retrieved from https://www.inegi.org.mx/temas/mg/default.html\#Mapa.

Instituto Nacional de Estadística, Geografía e Informática (INEGI). (2019). Mapoteca digital (Versión 3.0). Retrieved from http://solgeo.inegi.org.mx/mapoteca/frames.html?layer $=100 \& \mathrm{map}=\% 2 \mathrm{Fvar} \% 2 \mathrm{Fwww} \% 2 \mathrm{Fhtdocs} \% 2 \mathrm{Fma}$

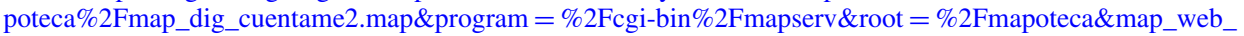
imagepath $=\% 2 \mathrm{Fvar} \% 2 \mathrm{Fwww} \% 2 \mathrm{Fhtdocs} \% 2 \mathrm{Fms} \_t \mathrm{mp} \% 2 \mathrm{~F} \& \mathrm{map} \_w e b \_i m a g e u r l=\% 2 \mathrm{Fms}$ ttmp $\% 2 \mathrm{~F} \& b o x=$ false \&drag $=$ true.

Jiménez, A., \& Hortal, L. (2003). Las curvas de evaluación silvestre y la necesidad de evaluar la calidad de los inventarios biológicos. Revista Ibérica de Aracnología, 8, 151-161.

Moreno, C. E. (2001). Métodos para medir la biodiversidad. M\&T-Manuales y Tesis SEA, vol. 1. Zaragoza.

Morón, M. A. (2013). Introducción al conocimiento de los escarabajos de Puebla. In M. A. Morón, A. Aragón-García, \& H. Carrillo Ruiz (Eds.), Fauna de escarabajos del estado de Puebla. Escarabajos Mesoamericanos A.C. (p. 128). Veracruz: Coatepec.

Novelo-Gutiérrez, R., \& Gómez-Anaya, J. A. (2009). A comparative study of Odonata (Insecta) assemblages along an altitudinal gradient in the sierra de Coalcomán Mountains, Michoacán, Mexico. Biodiversity \& Conservation, 18(3), 679-698.

Palacino-Rodríguez, F. (2011). Taxonomía y filogenia del género Erythemis Hagen, 1861 (Odonata: Libellulidae) (Unpublished doctoral dissertation). Universidad Nacional de Colombia, Bogotá.

Santillán Gutiérrez, E., Dávila-Vázquez, G., Sánchez, J. D. A., Torres, D., \& de Jesús, J. (2013). Estimación del balance hídrico mediante variables climáticas, en la cuenca del río Cazones, Veracruz, México. Revista Ambiente \& Agua, $8(3), 104-117$.

Schorr, M., \& Paulson, D. (2019, December 25). World Odonata list. Retrieved from http://www.pugetsound.edu/acade mics/academic-resources/slatermuseum/biodiversity-resources/dragonflies/world-odonatalist/.

Silva-Hurtado, J. D. (2019). Fauna de odonatos (Insecta: Odonata) de una localidad del municipio de Tlacuilotepec, Sierra Norte de Puebla, México (Unpublished bachelor's dissertation). Universidad Autónoma del Estado de Hidalgo, Mineral de la Reforma, Hidalgo, México.

Tapia-Rojas, A. M., Novelo-Gutiérrez, R., \& López-Olguín, J. F. (2005). Listado de “Odonatos” (Insecta: Odonata) depositados en la Colección Entomológica del Instituto de Ciencias de la Benemérita Universidad Autónoma de Puebla. Entomología Mexicana, 2: 864-867.

Toledo, V. M. \& Ordóñez, M. (1993). The biodiversity scenario of Mexico: A review of terrestrial habitats. In: T. P. Ramamoorthy, R. Bye, A. Lot, \& J. Fa (Eds.), Biological diversity of Mexico. Origins and distribution (pp. 757-777). New York: Oxford University Press.

Valenzuela-Rojas, J. (2015). Diversidad de odonatos (Insecta: Odonata) en el centro de investigación y educación ambiental "La Tribuna", Vereda Tamarindo (Neiva-Huila). Entomología Mexicana, 2, 619-627.

Villareal, H., Álvarez, M., Córdoba, S., Escobar, F., Fagua, G., Gast, F. . . Umaña, A. M. (2006). Métodos para el análisis de datos: Una aplicación para resultados provenientes de caracterizaciones de biodiversidad [Methods for data analysis: An application for results from biodiversity characterizations]. Bogotá, Colombia: Instituto de Investigación de Recursos Biológicos Alexander von Humboldt.

Wolf, M., Matthias, U., \& Roldan, G. (1988). Estudio del desarrollo de los insectos acuáticos, su emergencia y ecología en tres ecosistemas diferentes en el departamento de Antioquia. Actualidades Biológicas, 17(63), 2-27. 